\title{
Evolving Fisheries: Today's Bycatch is Tomorrow's Target Catch - Escolar (Lepidocybium flavobrunneum) Catch in the U.S. Pelagic Longline Fishery
}

\author{
Juan C. Levesque*
}

Geo-Marine, Inc., Environmental Resources Division, Marine Science Department, 2201 Avenue K, Suite A2, Plano, Texas 75074

\begin{abstract}
Wildlife and fisheries management are based upon economics: the law of supply and demand controls the direction of commercial fisheries. In the U.S. pelagic longline fishery, one example of a bycatch species that has received little research attention because of its lower economic value is the escolar (Lepidocybium flavobrunneum). Given its importance as a secondary market species, the main objectives of this paper are to provide information on fishing characteristics, relative abundance, distribution, and size composition of escolar catch in the U.S. pelagic longline fishery operating in the western North Atlantic. The overarching goal is to emphasize the importance of evaluating, managing, and conserving lower-valued species. Findings show that escolar nominal catches significantly vary by geographical area, month, and year. Most escolar are caught in the Gulf of Mexico and off the Florida East Coast (FEC), but mean catch rates are greatest in the FEC and Sargasso Sea. Escolar catch rates are greatest in April, November, and December. Overall, escolar catch rates are stable, which suggests that overfishing is not occurring in this part of the Atlantic.
\end{abstract}

Keywords: Commercial fisheries, ecosystem management, mesopelagic, secondary species, underutilized species, western North Atlantic Ocean.

\section{INTRODUCTION}

Wildlife and fisheries management are based upon economics. As such, it becomes apparent as to why global commercial fisheries target certain species in specific areas. Since the establishment of commercial fisheries, there has been only one "universal" law that supersedes all others when it comes to economic markets: the law of supply and demand. In general, commercial fisheries only exist because of this common law, which typically controls the direction of all commercial fisheries. Historically, commercial fishery markets have evolved or emerged to balance this fundamental law. Often these dynamics change so rapidly that it is difficult for fishery policy managers to keep pace. For instance, in 2005, National Marine Fisheries Service (NMFS) personnel received information indicating commercial fishermen were beginning to target whiting (Menticirrhus americanus) using sink gillnet gear in offshore northeastern Florida waters during the North Atlantic right whale (Eubalaena glacialis) calving season [1]. Because of the potential threat to right whales, NMFS subsequently imposed restrictions that eventually closed the fishery. As long as commercial fishery stocks continue to decline, new gear, techniques, target species, and markets will become established.

*Address correspondence to these authors at the Geo-Marine, Inc., Environmental Resources Division, Marine Science Department, 2201 Avenue K, Suite A2, Plano, Texas 75074, USA; Tel: 972-423-5480; Fax: 972-4222736; E-mail: jlevesque@geo-marine.com
Two of the greatest challenges of fisheries management are controlling bycatch in commercial fisheries [2] and understanding emerging fishery markets. Discards of bycatch is a significant problem in world fisheries. Alverson et al. [3] estimate that bycatch in the western North Atlantic Ocean is 81,665 metric tons $(\mathrm{mt})$ and around 210,000 $\mathrm{mt}$ in the eastern North Atlantic Ocean. Unfortunately, every commercial fishery has a suite of bycatch species that is discarded (dead or alive) at sea because they have little to no current economic value. With time, however, markets can become established for some of these presently undesirable species. Acknowledging that today's bycatch (i.e., species having little to no current economic value) might be tomorrow's target catch (i.e., species landed and sold for profit), it is essential that studies evaluate underutilized species in the present day because these species might require stringent fishery management (e.g., size limits, quotas, seasonal closures) in the future, especially if these species are long-lived (e.g., sharks) and vulnerable to overfishing. Studies on secondary species are important because the findings might inform fishery managers of fishing practices and catch characteristics that could prevent future overfishing. Depending on the market price for a particular species, the dynamics of an emerging fishery can cause overfishing before policy managers are even aware of any concerns $[4,5]$. Emerging fisheries $[5,1]$ and their importance [6] have been reported sporadically in the literature. The establishment of new fisheries prior to implementation of management control is problematic for policy managers. As an example, many researchers believe that most sharks (long-lived species, late-to-mature, and low reproductive rates) are overfished and populations 
are at critical levels because of their historical lower economic value [7]. Anderson et al. [6] assert that the quantitative knowledge of a species is positively related to its economic value; it is the greatest for 30- to 100-year-old fisheries. Fishermen and fishery policy managers have always understood that there is a connection between fish stocks and their ecosystem [8]. Nonetheless, fishery policy managers have historically managed fisheries using the single-species approach even though multiple species are often caught by one gear. Because this approach has failed at sustaining most global fish populations, fishery management is evolving toward ecosystem and biodiversity preservation [9, 10]. As such, bycatch studies will ultimately become more important to fishery managers and ecosystem modelers as this management approach becomes the standard.

In the U.S. pelagic longline fishery, one example of a bycatch species that has received little research attention because of its lower economic value is the escolar (Lepidocybium flavobrunneum). At one time, escolar was a worthless bycatch of the tuna (Thunnus spp) and swordfish (Xiphias gladius) pelagic longline fisheries. Today, escolar still do not support a directed fishery, but this species is now landed, marketed, and sold for a profit in the U.S. [11] and other regions [4]. The escolar is one of 23 species classified under the family Gempylidae, which consists of medium to largesize, carnivorous, pelagic fishes found in tropical and temperate seas [12]. Escolar is a mesopelagic fish that migrates from deep $(200-885 \mathrm{~m})$ to shallow waters $(<150 \mathrm{~m})$ at night to feed $[13,14]$. Besides a few studies describing its occurrence in commercial fisheries [4, 15-17], the biology and ecology of this species has yet to be completely investigated. To date, most published studies describe the escolar's indigestible wax esters and oily flesh, which can cause undesirable affects on human stomachs $[18,19]$. Despite its relative commercial importance, little has been documented about escolar catch characteristics in commercial fisheries. At present, the only comprehensive and quantitative study on escolar catch in pelagic longline fisheries was conducted in the western South Atlantic Ocean, which suggests that the escolar population size is declining as a result of commercial fisheries [4]. Specifically, Milessi and Defeo [4] found that the individual mean weight of escolar in pelagic longline catches significantly decreased over a 16 year period (19811996). Given its importance as a secondary market species and the lack of catch information for the western North Atlantic Ocean, the main objectives of this paper are to provide information on fishing characteristics, relative abundance, distribution, and size composition of escolar catch in the U.S. pelagic longline fishery. The overarching goal is to emphasize the importance of evaluating, managing, and conserving lower-valued species.

\section{MATERIALS AND METHODS}

\section{Data}

The data examined were compiled and maintained by the NMFS Southeast Fisheries Science Center (SEFSC) as part of the Pelagic Observer Program (POP) and include data collected since the POP's inception (June 1992-December 1999). In the U.S., fishery observer coverage is mandatory for Federal swordfish permit holders, and selection of a vessel for coverage is based on a random draw according to commercial fishing effort. Fishery observer coverage is based on the percentage of longline sets in a given area and calendar quarter (quarter 1: January-March, quarter 2: AprilJune, quarter 3: July-September, quarter 4: OctoberDecember). At the time of this study, the goal of the POP was to observe about $5 \%$ of the total reported sets for a given area and calendar quarter based on the previous year's fishing effort [20]. Historically, annual observer coverage typically ranged between 3 and $4 \%$ of longline sets [20, 21]. Today, observer coverage now exceeds $5 \%$ and was 10.8 and $14.9 \%$ in 2007 and 2008, respectively.

\section{Field Collections}

Fishery observers recorded fishing characteristics (e.g., number of hooks, floats, and depth), catch (species, size, and sex), status of catch (unknown, alive, dead, or damage), and action of catch (unknown, released alive, released dead, kept, finned, lost, or tended) while onboard "selected" U.S. pelagic longline vessels operating in the western North Atlantic Ocean from 1992 to 1999. If fish were brought onboard, they were identified (species and sex) and measured (Fork Length [FL]) to the nearest $(\mathrm{cm})$; however, if fish were released (discarded alive, dead, damaged, or lost) back to the water, FL was estimated to the nearest foot (ft) by fishery observers located near the hauling station. On average, fishery observers were about 3 to $15 \mathrm{~m}(10-50 \mathrm{ft})$ away from the catch when the mainline was hauled. All fish landed and retained were weighed to the nearest ounce (28.3 grams) after the catch was unloaded at the dock [20].

\section{Fishing Gear and Techniques}

The U.S. pelagic longline fishery targets both swordfish and tuna with longline gear. Pelagic longline gear consists of a heavy monofilament (700-900 lb test) mainline (7-65 kilometers long) that is suspended in the water column by a series of floats (dropline-float and monofilament line), high flyer buoys, and radio beacons. Between the floats, gangions (leaders [35-60 m long] with baited 9/0 J-style hooks [Mustad \#7698 or Eagle Claw \#9016]) are attached to the mainline using stainless steel longline clips at a regular interval (3-5 hooks between each float) determined by the fishing captain [20]. Today, the NMFS requires all hooks in the pelagic longline fishery to be circle hooks to reduce sea turtle mortality [22]. In the NMFS Northeast Distant (NED) statistical area, circle hooks must be $18 / 0$ or larger and the offset must not exceed 10 degrees when using whole Atlantic mackerel (Scomber scombrus) or squid (Illex spp.) as bait. Outside of the NED, circle hooks must be18/0 or larger with an offset not to exceed 10 degrees; however, $16 / 0$ or larger non-offset circle hook can also be used when baiting with whole fish or squid. When vessels target swordfish, fishermen attach a chemical light stick to the leader around 2 meters (m) above the hook; light sticks are not used for targeting tuna [20]. On average, the number of hooks set per event (i.e., one fishing day) is between 400 and 1200 hooks. Fishermen that target swordfish set gear at sunset and haul back at sunrise. However, fishermen that target tuna set gear at sunrise and haul back at sunset [20,23]. Regardless of the target species, pelagic longline fishing captains set gear in association with ocean currents and sea surface temperatures (e.g., Gulf Stream current). Gear is allowed to float freely 


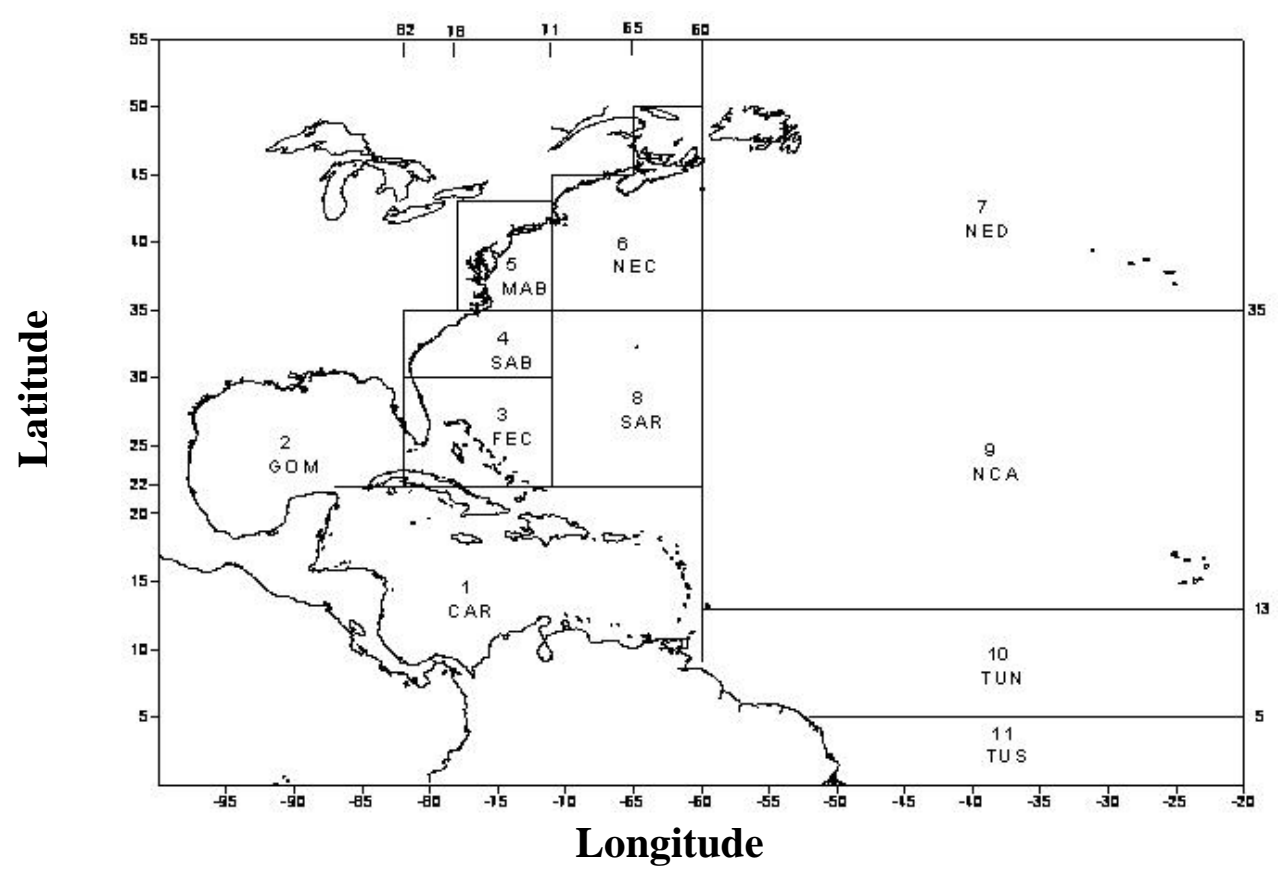

Fig. (1). Map of the study area in the western North Atlantic Ocean illustrating the NMFS statistical areas (Lee and Brown, 1998). The NMFS statistical areas are as follows: 1) Caribbean (CAR); 2) Gulf of Mexico (GOM); 3) Florida East Coast (FEC); 4) South Atlantic Bight (SAB); 5) Mid-Atlantic Bight (MAB); 6) Northeast Coastal (NEC); 7) Northeast Distant (NED); 8) Sargasso (SAR); 9) North Central Atlantic (NCA); 10) Tuna North (TUN); and 11) Tuna South (TUS).

with the current and soak times for each set range from 6 to 14 hours.

\section{Study Area}

The pelagic longline fishing grounds for the U.S. commercial fishing fleet extends from the Grand Banks in the North Atlantic Ocean to the waters off South America ( 5$10^{\circ}$ North Latitude), including the Caribbean Sea and the Gulf of Mexico. For research and management purposes, the NMFS divides the western North Atlantic Ocean (including the Gulf of Mexico and Caribbean) into 11 geographical statistical areas thought to represent regions of similar types of fishing effort (20, 23; Fig. 1).

\section{Statistical Analysis}

Prior to analyses, all datasets were tested for normality and homoscedacity (variance [equivalently standard deviation] is equal) using Kolmogorov-Smirnov [24] and Bartlett tests $[25,26]$, respectively. If the datasets passed normality, then parametric procedures were employed. Otherwise, the data were $\log$-transformed $[\log (\mathrm{X}+1)]$ to meet the underlying assumptions of normality [24]. If after transformation the data still did not meet the assumptions of normality, then non-parametric tests were applied. For all analyses, statistical significance was defined as $P<0.05$. In the presence of significance at the $95 \%$ confidence level for the omnibus Analysis of Variance (ANOVA) or Kruskal-Wallis nonparametric multi-sample test, a post-hoc multiple comparison test (Student-Newman-Keuls [SNK]) was used to perform pairwise comparisons. All post-hoc multiple comparison test results were presented in ascending order. All analyses were conducted using Microsoft Excel $^{\circledR}$ and various analysis add-on features for Microsoft Excel.
The use of catch-per-unit-effort (CPUE) has been a standard method for assessing relative abundance in fishery science since the late 1980s [27]. The number of fish caught in a fishery is often considered proportional to their abundance [28]. Following this notion, relative abundance and distribution was estimated and compared among NMFS statistical areas, months, and years. Analysis was only conducted for sets in which escolar were taken (positive catch). Catch-perunit-effort was calculated for each set as the ratio between the number of escolar taken and the number of hooks fished. For comparative studies, catch rates were raised to the number of escolar taken per 1000 hooks. For these analyses, it was assumed that fishing factors (e.g., bait, hooks, or weather) did not affect catch rates, so CPUE was reported as nominal, and explanatory factors were not considered or evaluated. Three separate ANOVA tests were used to determine if any variations in nominal CPUE by areas, months, and years showed significant differences. Size composition was evaluated by generating Length Frequency Distribution (LFD) histograms by area, month, and year. An ANOVA test was used to determine if any variation in mean length by area, month, and year showed significant difference.

A Student's t-test was used to determine whether there was any significant variation in mean length between male and female escolar. The overall sex ratio of escolar was explored for heterogeneity using Chi-square analysis. The mean estimated FL of discarded to actual measured escolar was evaluated and compared using a Student's t-test.

\section{RESULTS}

\section{Fishing Characteristics}

In total, the number of hooks set by the U.S. pelagic longline fishery (1992-1999) ranged from 180,962 in 1998 to 


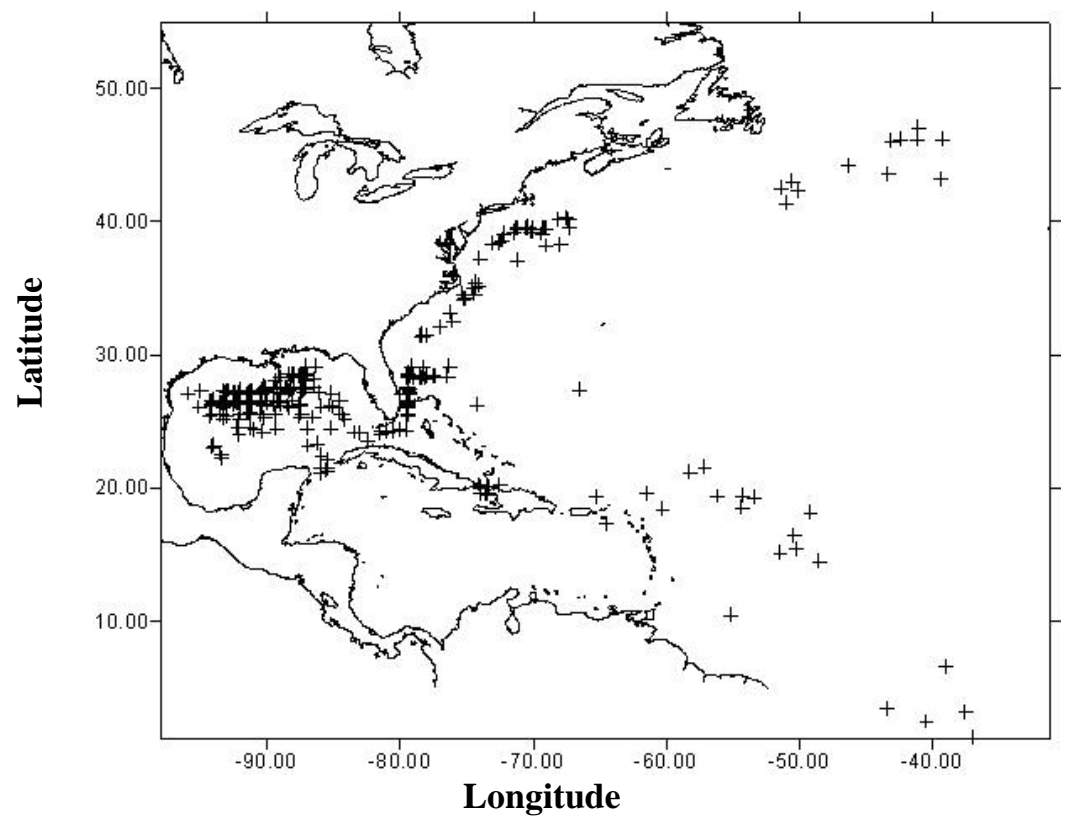

Fig. (2). Distribution of escolar (Lepidocybium flavobrunneum) observed taken in the U.S. pelagic longline fishery operating in the western North Atlantic Ocean during 1992 through $1999(n=2,995)$.

534,969 in 1993. Overall, fishery observers observed (percent coverage achieved) between 2.57 (44 hauls [1992]) and $5.48 \%$ (697 hauls [1995]) of the U.S. pelagic longline fishing effort in the western North Atlantic (1992-1999). Of the observed hauls, escolar were taken in waters having a bottom depth ranging from 333 to 8,437 meters $(\mathrm{m})$. The minimum bottom depth where escolar were taken significantly varied by NMFS statistical area $[\mathrm{F}(10,1222)=55.77, P<0.001]$. The shallowest depth was in the FEC (mean $=332.7 \mathrm{~m}$, S.D. $=279.7$ ) and the deepest was in the TUN (mean $=2,972.7 \mathrm{~m}$, S.D. = 1,215.3). A post-hoc multiple comparison test showed there was no significant difference between the minimum bottom depth (presented in ascending order) and the following NMFS statistical areas: (a) 6, 4, and 5; (b) 2, 1, and 8; (c) 1,8 , and 11 ; and (d) $8,11,9,7$, and 10 .

The minimum fishing hook-depth (length of float line plus length of gangion) where escolar were taken ranged from 3 to $291 \mathrm{~m}$ with a mean of $51 \mathrm{~m}$. The maximum fishing hook-depth ranged from 13 to $396 \mathrm{~m}$ with a mean of $69 \mathrm{~m}$. The minimum fishing hook-depth where escolar were taken significantly varied by NMFS statistical area $[\mathrm{F}(10,1222)=$ 42.57, $P<0.001]$. The shallowest fishing hook-depth set was in the NEC (mean $=12.9 \mathrm{~m}$, S.D. $=3.3)$ and the deepest in the TUN (mean $=37.8 \mathrm{~m}$, S.D. = 5.7). A post -hoc multiple comparison test showed there was no significant difference between the minimum fishing-hook depth set (presented in ascending order) and the following NMFS statistical areas: (a) 6, 7, 5, 4, and 8; (b) 4, 8, and 3; (c) 8, 3, 2, and 11; and (d) $2,11,1,9$, and 10 .

The total number of hooks set where escolar were taken ranged from 111 to 1,438 with a mean of 692 . The least number of hooks were set in the FEC (mean $=327.1$, S.D. $=$ 119.2) and the most in the NED (mean $=875$, S.D. $=329)[\mathrm{F}$ $(10,1022)=64.41 ; P<0.001]$. A post-hoc multiple comparison test showed there was no significant difference be- tween the number of hooks set (presented in ascending order) and the following NMFS statistical areas: (a) 3 and 8; (b) $8,1,10$, 4, and 5; (c) 10, 4, 5, 9, 2, 11, and 6; and (d) 11, 6 , and 7 .

The total number of hooks set in the GOM (the geographical area with the greatest overall escolar catch) significantly varied among years $[H=44.48 ; P<0.001]$. The least number of hooks set was in 1992 (mean $=638.5$, S.D. $=$ 245.9) and the most in 1993 (mean $=809.1$, S.D. 259.4). A post-hoc Tukey multiple comparison test showed there was no significant difference between the number of hooks set (presented in ascending order) and the following years: (a) 1992, 1999, 1997, 1996, 1994, and 1998; (b) 1996, 1994, 1998, and 1995; and (c) 1994, 1998, 1995, and 1993.

The total number of hooks set in the FEC (the area with greatest escolar abundance) significantly varied among years $[H=44.63 ; P<0.001]$. The least number of hooks set was in $1992($ mean $=198.8$, S.D. $=31.5)$ and the most in 1993 $($ mean $=412.2$, S.D. $=119.3)$. A post-hoc Tukey multiple comparison test showed there was no significant difference between the number of hooks set (presented in ascending order) and the following years: (a) 1992, 1994, and 1996; (b) 1994, 1996, 1999, and 1997; and (c) 1994, 1996, 1999, 1997, 1998, 1995, and 1993.

\section{Abundance and Distribution}

In total, fishery observers reported 3,494 escolar ( $n=$ 2,995 measured; $n=498$ unmeasured) taken by the U.S. pelagic longline fishery operating in the western North Atlantic Ocean (1992-1999). The total number of escolar taken per set ranged from 1 to 38 individuals. Escolar were taken in every year and NMFS statistical area, but most were taken in the GOM (77\% or $n=2,311$; Figs. 2 and 3$)$ and the FEC $(6 \%$ or $n=186)$. The NMFS statistical area with the least number of escolar taken was in the TUS $(0.1 \%$ or $n=4)$. 


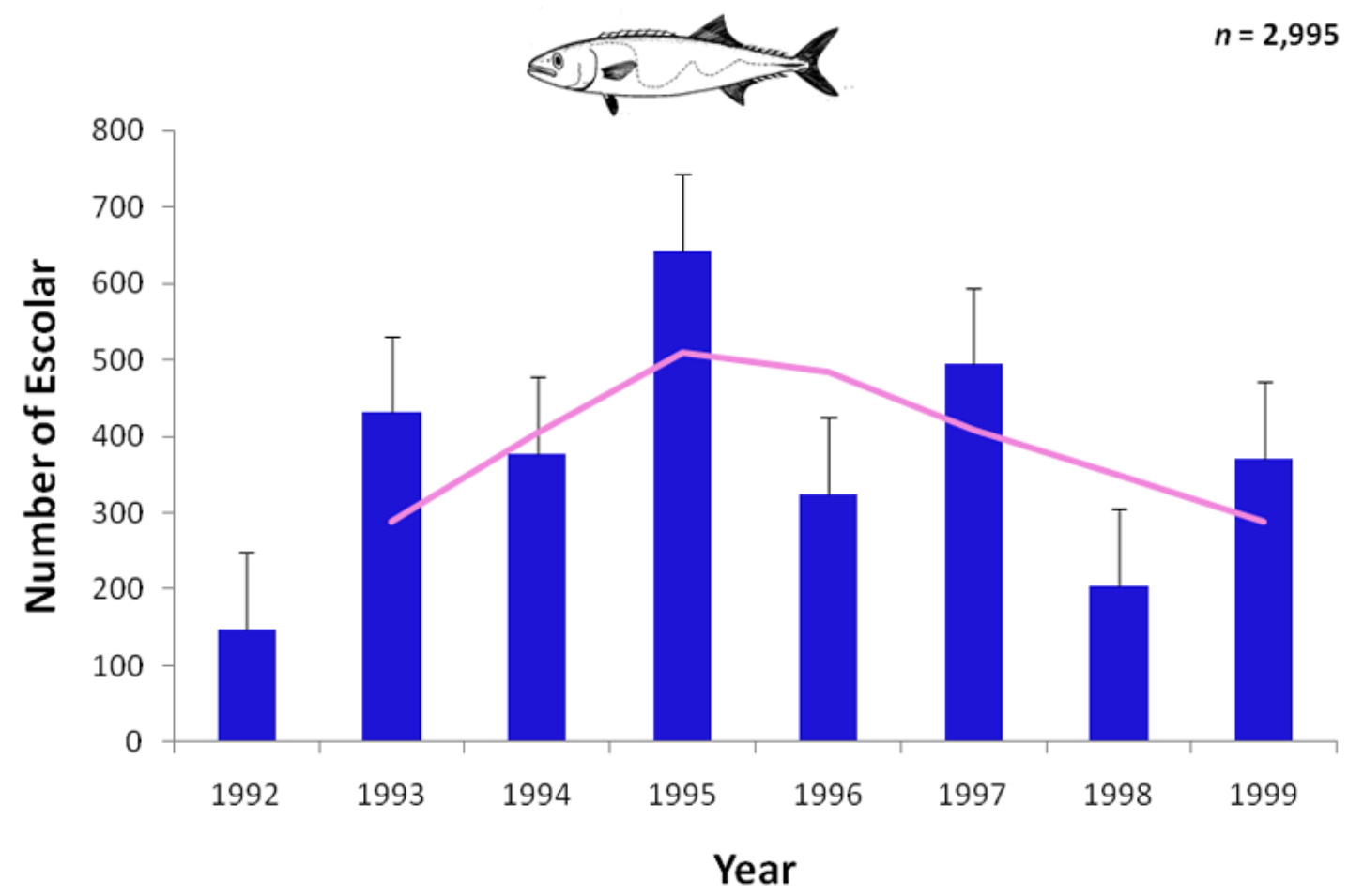

Fig. (3). Total number of escolar (Lepidocybium flavobrunneum) observed taken in the U.S. pelagic longline fishery operating in the western North Atlantic Ocean $(1992-1999 ; n=2,995)$. Mean \pm 1 S.E. (error bars) and the solid line depicts the moving average.

Overall, relative escolar abundance varied by area, month, and year. Nominal escolar catch rates ranged from 1.99 (MAB and TUS) to 8.09 escolar per 1,000 hooks (FEC), and a significant difference was detected (ANOVA, $P<$ 0.001; Fig. 4). A post-hoc multiple comparison test showed there was a significant difference between FEC and MAB (SNK test, $P<0.05$ ). In general, mean escolar catch rates were negatively correlated from western to eastern NMFS statistical areas. This observation was explained by simple linear regression: mean CPUE $=-0.4889$ (NMFS statistical area) + 5.9289; $\mathrm{r}^{2}=0.60$ (Fig. 4)

The monthly number of escolar taken ranged from 124 in March to 575 in November. More specifically, catches of escolar in the GOM and the FEC were greatest in May and November and lowest in January and February. The overall moving average showed that escolar catches generally increased from summer (July) to fall (November). Nominal monthly escolar catch rates ranged from 3.65 (February) to 9.36 escolar per 1,000 hooks (November), and a significant difference was detected (ANOVA, $P<0.001$; Fig. 4). A post-hoc multiple comparison test showed there was a significant difference between November and the other months, and between December and February (SNK test, $P<0.05$ ).

The total number of escolar taken ranged from 148 in 1992 to 643 in 1995 (Fig. 3). Catches of escolar displayed an alternating pattern, with more escolar taken every other year, and catches slightly declining with time. Nominal annual escolar catch rates ranged from 4.22 in 1998 to 9.63 escolar per 1,000 hooks in 1992, and significant difference was detected (ANOVA, $P<0.001$; Fig. 4). A post-hoc multiple comparison test showed there was a significant difference in CPUE between 1992 and the other years, and between 1993 and 1998 (SNK test, $P<0.05$ ).
Overall, the U.S. pelagic longline fishery caught more female escolar $(n=1,536)$ than male escolar $(n=827)$, and the sex ratio of male-to-female was 1:1.86 $(P<0.05)$. Observations on the status of escolar upon gear retrieval showed there was no significant difference between live $(56 \%)$ and dead $(44 \%)(P>0.05)$.

\section{Size Composition}

Escolar measured by fishery observers ranged in length from 18 to $182 \mathrm{~cm}$ FL (median $=86.0 \mathrm{~cm} \mathrm{FL}$, mode $=74.0$ $\mathrm{cm}$ FL, mean $=89.5 \mathrm{~cm} \mathrm{FL;} n=2,995)$, and the lengthfrequency distribution (20-200 cm FL) did not suggest a normal distribution; size-classes were slightly skewed toward smaller sizes $(D=0.066 ; P<0.001$; Fig. 5). Escolar that were unable to be measured by fishery observers ranged in length from 15 to $305 \mathrm{~cm}$ FL (median $=86.0 \mathrm{~cm} \mathrm{FL}$, mode $=70.0 \mathrm{~cm} \mathrm{FL}$, mean $=87.1 \mathrm{~cm} \mathrm{FL} ; n=498)$, and the data did not suggest a normal distribution $(D=0.065 ; P<$ 0.001). A Student's t-test showed there was no significant difference between escolar that were measured and those that were unable to be measured $(P=0.0522)$.

Escolar dressed weights (DW) ranged from 3.17 to 38.09 $\mathrm{kg}$ with a mean of $13.79 \mathrm{~kg}(n=44)$. The FL to DW association was best described by exponential regression (DW = $0.9209 \mathrm{e}^{0.0246(\mathrm{FL})} ; \mathrm{r}^{2}=0.858$; Fig. 6) rather than by power regression $\left(\mathrm{DW}=0.0003(\mathrm{FL})^{2.3226} ; \mathrm{r}^{2}=0.814\right)$.

Overall, escolar mean size varied by area, month, and year. The mean escolar length ranged from $83.5 \mathrm{~cm}$ FL in the $\mathrm{SAB}$ to $129 \mathrm{~cm}$ FL in the SAR, and a significant difference was detected (ANOVA, $P<0.001 ;$ Figs. 7, 8). A posthoc multiple comparison test did not show any significant difference in escolar length (presented in ascending order) 

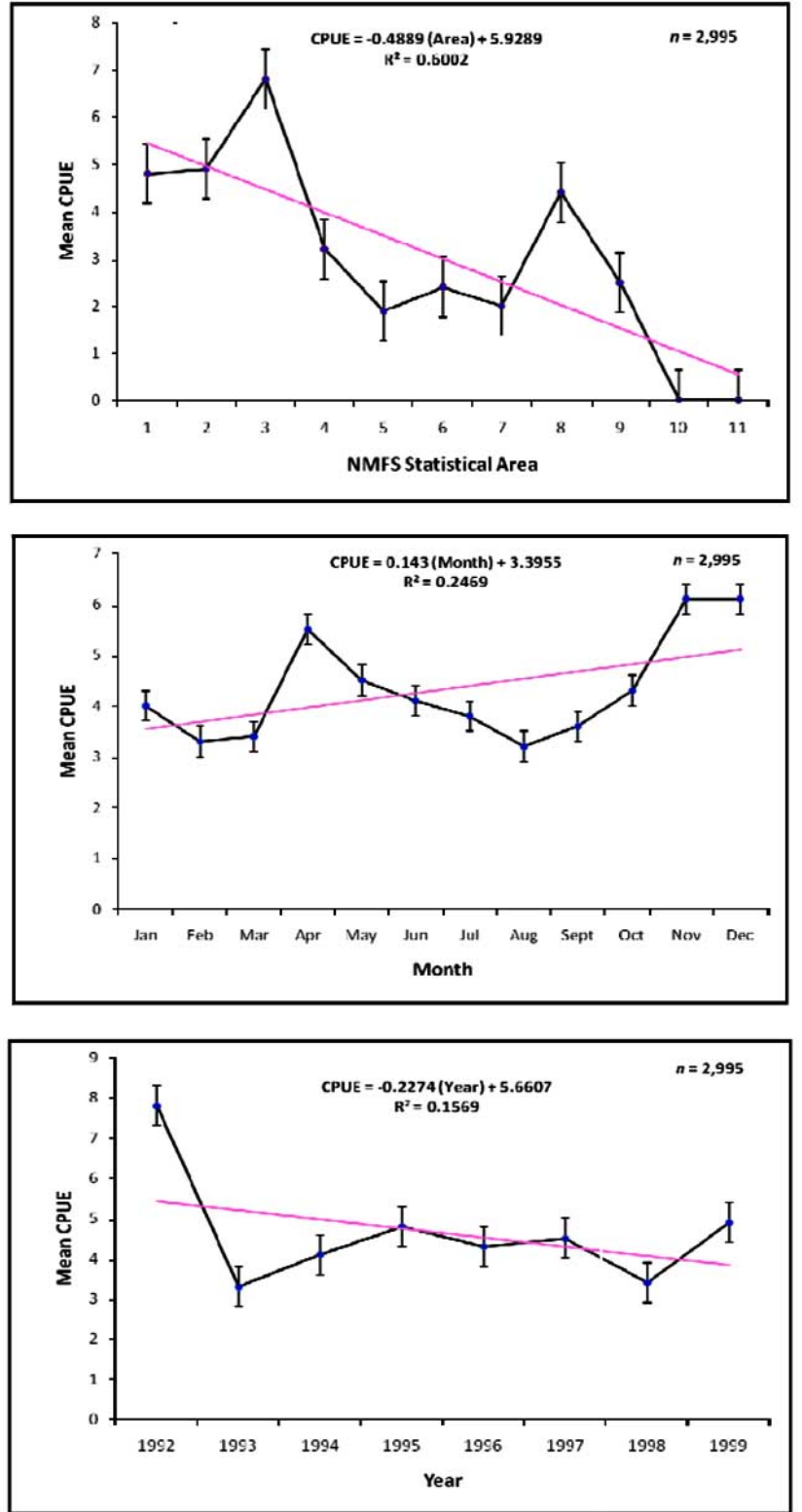

Fig. (4). Nominal catch rates by area, month, and year for escolar (Lepidocybium flavobrunneum) observed taken in the U.S. pelagic longline fishery operating in the western North Atlantic Ocean (1992-1999; $n=2,995)$. The NMFS statistical areas are as follows: 1) Caribbean (CAR); 2) Gulf of Mexico (GOM); 3) Florida East Coast (FEC); 4) South Atlantic Bight (SAB); 5) Mid-Atlantic Bight (MAB); 6) Northeast Coastal (NEC); 7) Northeast Distant (NED); 8) Sargasso (SAR); 9) North Central Atlantic (NCA); 10) Tuna North (TUN); and 11) Tuna South (TUS). Catch rates are expressed as the mean number of escolar caught per 1000 hooks set. Mean \pm 1 S.E. (error bars) and the solid line depicts the linear regression.

and the following NMFS statistical areas: (a) 10, 9, 3, 11, 7, $1,5,6$, and 8; and (b) 4, 2, 10, 9, 3, 11, 7, 1, 5, 6, and 8 .

The mean escolar size ranged from $74.7 \mathrm{~cm}$ FL in September to $100.1 \mathrm{~cm}$ FL in March, and a significant difference was detected (ANOVA, $P<0.001$; Figs. 7, 8). A post-hoc multiple comparison test did not show any significant differ-

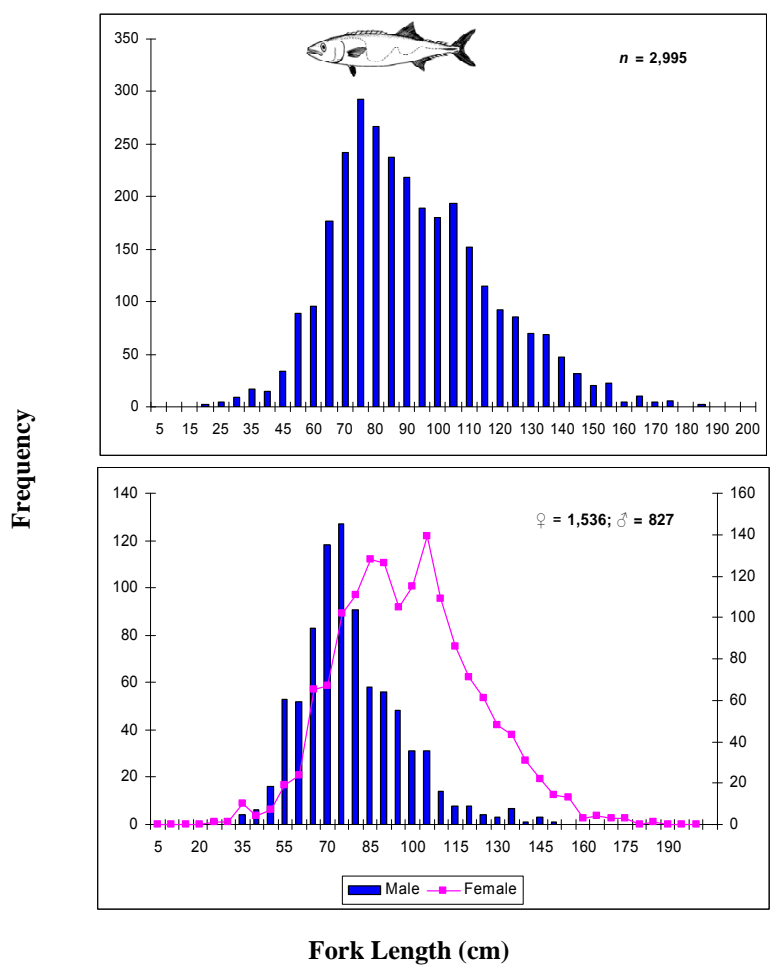

Fig. (5). Length frequency distribution for escolar (Lepidocybium flavobrunneum) observed taken in the U.S. pelagic longline fishery operating in the western North Atlantic Ocean during 1992 through 1999; $n=2,995$ ).

ence in escolar length (presented in ascending order) and the following months: (a) December, January, February, October, and March; (b) August, December, January, February, October, and March; (c) July, November, August, and December; (d) April, June, July, November, and August; and (e) May, April, June, and July.

The mean escolar length ranged from $81.5 \mathrm{~cm}$ FL in 1995 to $95.7 \mathrm{~cm}$ FL in 1993, and a significant difference was detected (ANOVA, $P<0.001$; Figs. $7, \mathbf{8}$ ). A post-hoc multiple comparison test did not show any significant difference in escolar length (presented in ascending order) and the following years: (a) 1996, 1999, 1998, 1992, and 1993; (b) 1997, 1996, 1999, 1998, and 1993; and (c) 1994 and 1997.

Male escolar ranged in length from 22 to $148 \mathrm{~cm} \mathrm{FL}$ $($ median $=74.0 \mathrm{~cm} \mathrm{FL}$, mode $=74.0 \mathrm{~cm} \mathrm{FL}$, mean $=76.0 \mathrm{~cm}$ FL), whereas female escolar ranged in length from 25 to 182 $\mathrm{cm}$ FL (median $=95.0 \mathrm{~cm} \mathrm{FL}$, mode $=102.0 \mathrm{~cm} \mathrm{FL}$, mean = $96.0 \mathrm{~cm}$ FL; Fig. 5). Male escolar were significantly smaller than female escolar (Student's t-test, $P<0.0001$ ) and data for either sex did not suggest a normal distribution ( $\widehat{D} D=$ $.085 ; P<0.001 ;$; $D=0.039 ; P<0.001$; Fig. 5).

\section{DISCUSSION}

\section{Fishing Techniques}

This study showed that the overall mean minimum depth for longline sets where escolar were taken was around 2,100 


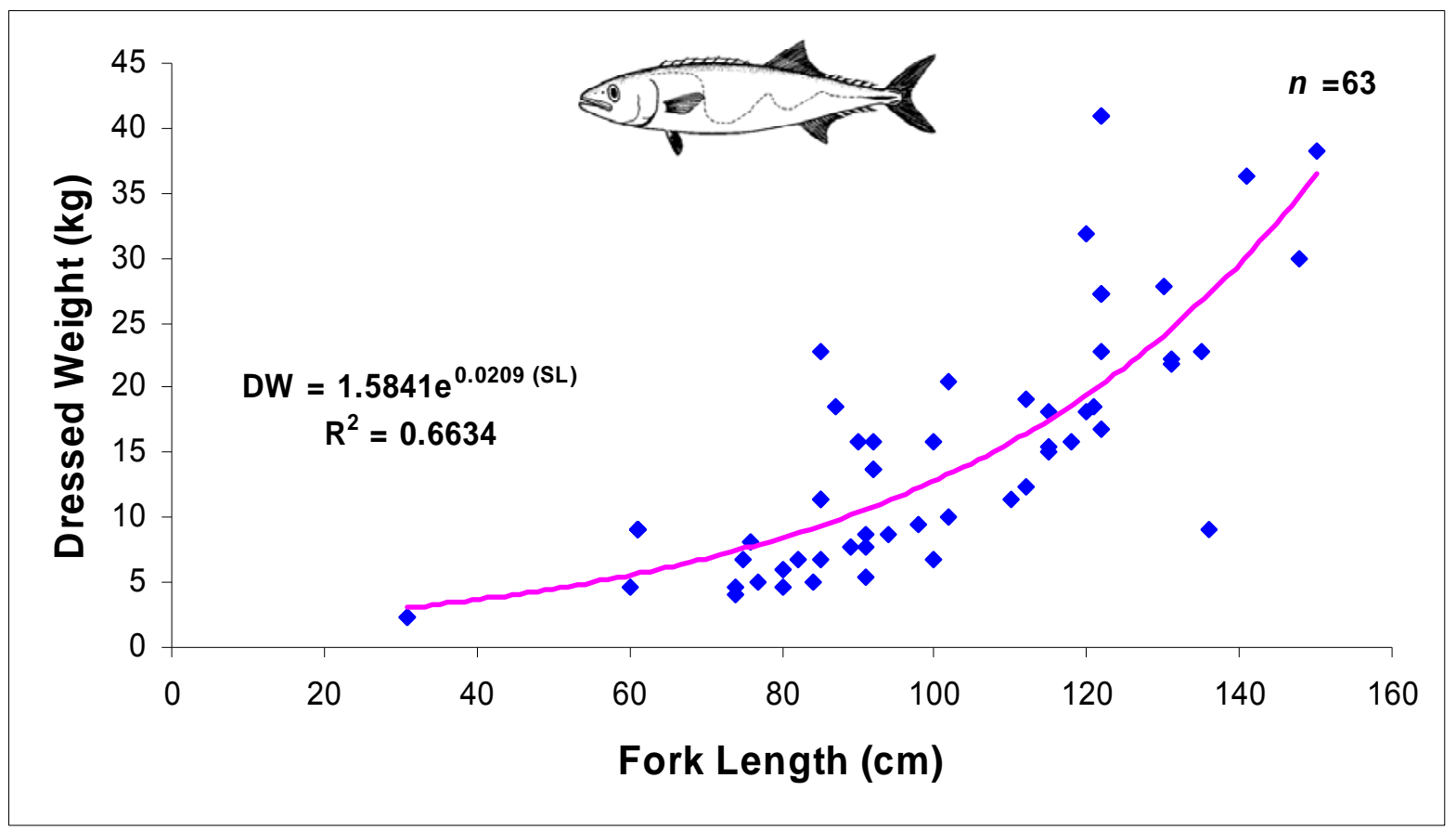

Fig. (6). Dressed weight-fork length exponential regression of escolar (Lepidocybium flavobrunneum) sampled from the U.S. pelagic longline fishery operating in the western North Atlantic Ocean during 1992 through 1999; $n=44$ ).

m. Although more escolar were taken in the Gulf of Mexico (i.e., the area with greatest escolar catch), the highest catch rates occurred off the Florida East Coast. Despite the mean minimum depths (GOM [2,109 $\mathrm{m}]$ and FEC [1,962 m]) being similar between both areas, the bottom depth in the Gulf of Mexico gradually slopes from inshore to offshore, whereas the bottom depth profile off the Florida East Coast (NMFS statistical area 3) decreases more sharply closer to shore. As such, this seems to suggest that there is a correlation between catches of escolar and bottom depth profile. In addition, these results indicate that escolar might have a habitat preference for nearshore waters that have bottom ridges, steep drop-offs, or ledge features, which agrees with the findings for escolar catches off the Pacific coast of Japan $[12,29]$.

The mean minimum hook-depth where escolar were taken was $51 \mathrm{~m}$ and the maximum hook-depth was $69 \mathrm{~m}$. Interestingly, the minimum and maximum hook-depths ranged from 35 to $83 \mathrm{~m}$ in NMFS statistical areas 2, 3, and 4, whereas the minimum and maximum hook-depths for NMFS statistical areas 5-7 ranged from 18 to $43 \mathrm{~m}$. In the tropical and offshore Atlantic region (NMFS statistical areas 1, 811 ), the minimum and maximum hook-depths were between 57 and $85 \mathrm{~m}$ [20]. Based on this information, it appears that catches of escolar are correlated with both bottom topography and vertical depth, which supports that notion that escolar prefer mid-water depths (i.e., mesopelagic species). In fact, Kerstetter et al. [14] found that escolar in the Caribbean Sea have distinct diel patterns with escolar spending daylight hours in depths greater than $250 \mathrm{~m}$ and nighttime hours in much shallower depths $(<250 \mathrm{~m})$. Kerstetter et al. [14] also found that escolar showed a strong correlation between depth and temperature. Although this current study did not evaluate moon phase in relation to catch rate, it is probable that greatest catches occurred during a new moon rather than a full moon; that is assuming fishermen did not change fishing tactics. For these analyses, it was assumed that gear specifications did not have an affect on catches of escolar, which is probably not the case. As such, it is recommended that future studies evaluate the affects of gear and techniques on catch, such as the number of hooks between floats. Although it would be challenging to differentiate from the POP data set, it should be explored. Information on fishing gear techniques and their influence on catch rates is limited, but anecdotal information suggests that fishermen will sometimes change their daily fishing routine (number of hooks or floats) according to their daily catch in hopes of increasing their success [30].

\section{Abundance and Distribution}

This study demonstrated that escolar relative abundance was greatest off the Florida East Coast and not only varied seasonally, but decreased from western to eastern areas. Catches of escolar in the western North Atlantic Ocean showed a clear and recurring seasonal pattern over the 8 year time span, with maximum catches occurring in May and November. In the Gulf of Mexico and Florida East Coast areas, peak catches of escolar occurred in November every year; the largest number of escolar taken in one set $(n=38)$ was in the Gulf of Mexico during November. It is difficult to speculate why catches of escolar generally peaked every year in late-spring (May) and fall (November), but this might be associated with either seasonal reproductive or feeding behaviors. Although no published reproductive information is available for escolar, size composition data showed that the smallest escolar taken (18.0 cm FL) was in August. Thus, assuming this individual was between 1 and 2 months old [29], then the hatch date was either in May or June, which 


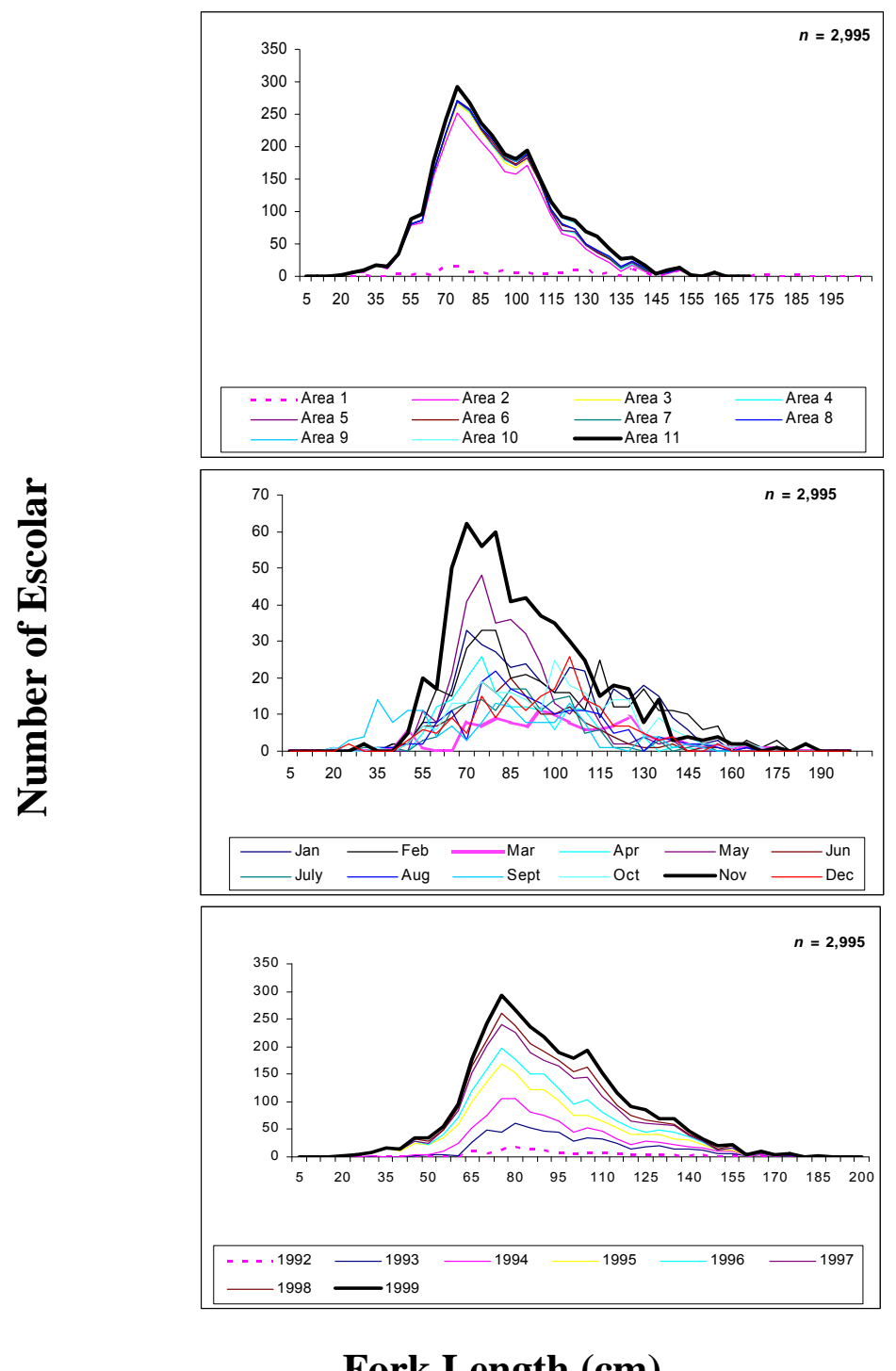

Fork Length (cm)

Fig. (7). Length-frequency distribution by NMFS statistical area, month, and year for escolar (Lepidocybium flavobrunneum) observed taken in the U.S. pelagic longline fishery operating in the western North Atlantic Ocean $(1992-1999 ; n=2,995)$. The NMFS statistical areas are as follows: 1) Caribbean (CAR); 2) Gulf of Mexico (GOM); 3) Florida East Coast (FEC); 4) South Atlantic Bight (SAB); 5) Mid-Atlantic Bight (MAB); 6) Northeast Coastal (NEC); 7) Northeast Distant (NED); 8) Sargasso (SAR); 9) North Central Atlantic (NCA); 10) Tuna North (TUN); and 11) Tuna South (TUS).

could explain peak catches in May. Nishikawa and Warashina [29] also observed seasonal variations in escolar catch in the Pacific Ocean, with peak escolar catches occurring in spring (April-June) and fall (September-November). In the western South Atlantic Ocean, Milessi and Defeo [4] found that most escolar catches occurred in winter and spring, which is similar to swordfish and tuna catches. As such, they speculated that escolar might share similar trophic and reproductive behaviors as species in higher trophic positions. In the eastern North Atlantic Ocean, Lorenzo and Pajuelo [31] reported that male and female reproductive activity (GSI) for round escolar (Promethichthys prometheus) increased from March to July, and age 1 escolar otolith opaque formation occurred in July or August. Although seasonal variation might be associated with reproductive behavior, it is more probable that peak catches in the western North Atlantic Ocean are associated with feeding behavior. In the open-ocean environment, the availability of food is often limited to specific areas of oceanic convergence (currents and sea mounts or ridges), which creates productive fishing conditions at certain times of the year. Therefore, it is possible that the combination of fishermen setting gear in historical productive fishing areas and presenting of a food source (longline gear with baits) during periods that might not support large concentrations of prey could help to explain why catches of escolar increased each year in May and November. The availability of prey and its influence on pelagic longline catch rates has yet to be investigated, but it is likely that prey and catch rates of target and incidental catch are negatively correlated.

The total annual number of escolar observed taken in the U.S. pelagic longline fishery ranged from 148 in 1992 to 643 in 1995. Overall, escolar catch increased during the periods 1992-1995 and 1998-1999, but declined 58\% after peaking 

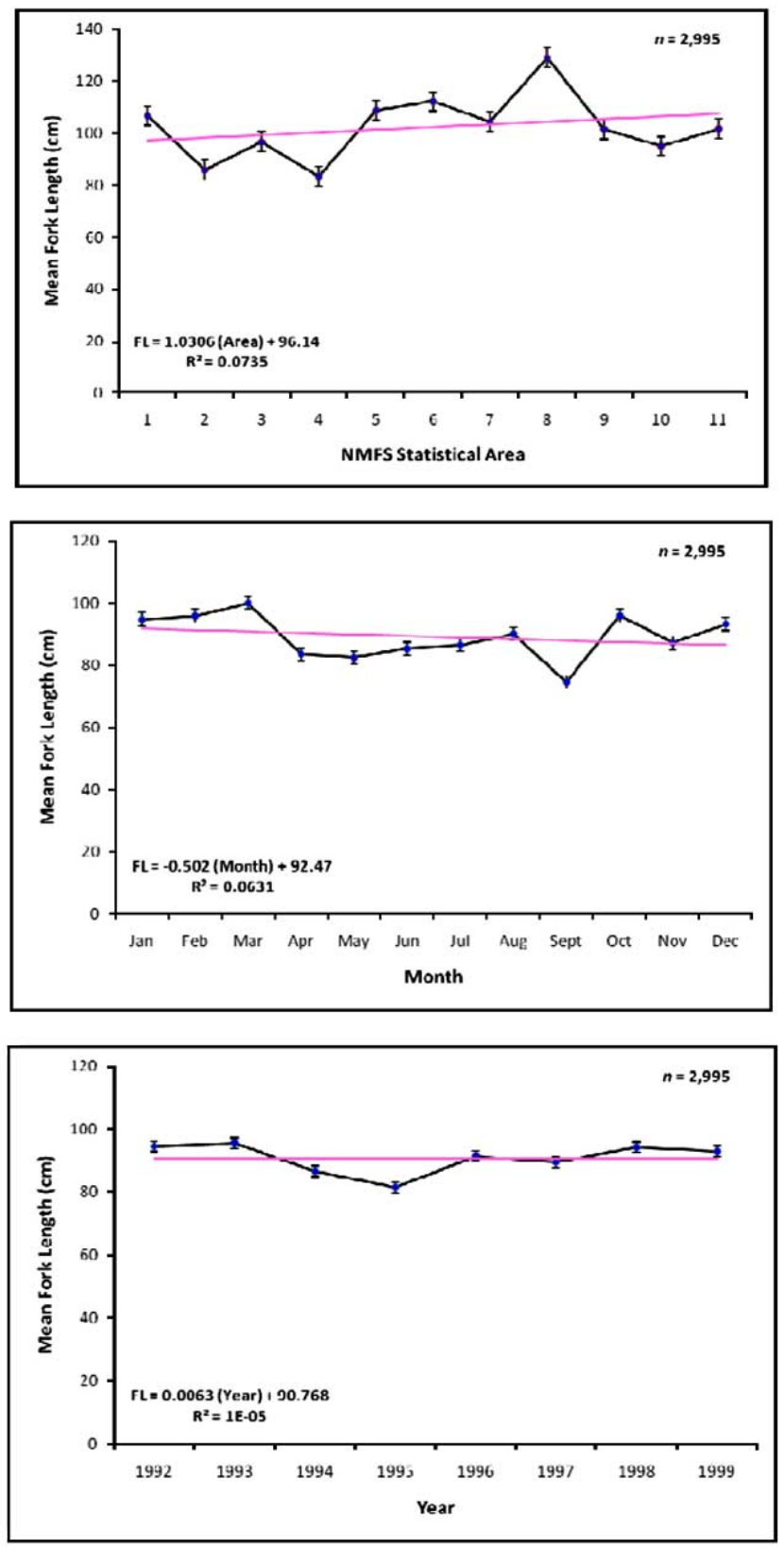

Fig. (8). Mean fork length distribution by area, month, and year for escolar (Lepidocybium flavobrunneum) observed taken in the U.S. pelagic longline fishery operating in the western North Atlantic Ocean (1992-1999; $n=2,995)$. The NMFS statistical areas are as follows: 1) Caribbean (CAR); 2) Gulf of Mexico (GOM); 3) Florida East Coast (FEC); 4) South Atlantic Bight (SAB); 5) MidAtlantic Bight (MAB); 6) Northeast Coastal (NEC); 7) Northeast Distant (NED); 8) Sargasso (SAR); 9) North Central Atlantic (NCA); 10) Tuna North (TUN); and 11) Tuna South (TUS). Mean \pm 1 S.E. (error bars) and solid line depicts the linear regression.

in 1995. Despite total escolar catch decreasing after 1995, overall relative abundance has remained stable even though the data showed that abundance significantly increased between years 1993 and 1999. At this time, these data do not suggest overexploitation. This notion is also supported by the fact that fishing effort, in terms of the number of hooks set, in the Gulf of Mexico and Florida East Coast has not increased with time. The combination of declining catch rates and an increase in fishing effort usually describes a fish stock population that is declining, unstable, and overexploited, which was evident for escolar in the western South Atlantic Ocean [4].

It is difficult to understand why the findings from this present study differ from those in the South Atlantic Ocean, but there are two possible explanations. One explanation could be that either escolar are more abundant in the South Atlantic Ocean and the fishery has impacted the population greater or possibly because fishing effort is more concentrated in the South Atlantic than in the North Atlantic. In the western North Atlantic Ocean, data showed that the fishing effort extends from the Northeast Distant to the Tuna South Atlantic waters covering a greater area and diversity of habitats than that of the South Atlantic. The catch rates of this present study ranged from 2 to 8 escolar per 1000 hooks, which was much higher than those reported by Nakano et al. [32] for escolar in Pacific waters. The higher estimated values from this present study are probably associated with target catch and fishing technique. Although the U.S. pelagic longline fishery targets both tuna and swordfish, most of the fishing effort is usually directed at swordfish, except for in the Gulf of Mexico where most fishermen target tuna. In contrast, data gathered by Nakano et al. [32] was obtained from fisherman specifically targeting tuna; fishermen use a different technique when targeting tuna. Nakano et al. [32] reported that fishermen targeting tuna set gear in the morning and retrieved gear from noon to midnight. In addition, the difference in catch rates is probably associated with the fact that fishermen tend to set gear deeper in the water column when targeting swordfish. Nevertheless, it is difficult to compare the two studies without analyzing factors, such as soak times, set and retrieval times, or gear fishing depth. Another possible explanation for the higher catch rates in the western North Atlantic is escolar behavior. New information by Kerstetter et al. [14] from the Caribbean Sea demonstrates that escolar migrate to shallower waters $(<250 \mathrm{~m})$ at night and deeper waters $(>250 \mathrm{~m})$ during the day. In addition, Kerstetter and Graves [17] showed, with hook timer technology, that escolar taken in the Mid-Atlantic Bight region had long hooked durations (i.e., time on the line) suggesting that escolar were caught on the line shortly after the gear was set. Again, this could explain why escolar catch rates were probably higher for sets in the Atlantic Ocean versus those in the Pacific Ocean. Finally, the higher catch rates in the Atlantic Ocean might be due habitat preference. As stated above, the continental shelf off the Florida east coast decreases sharply close to shore, which might provide better habitat for escolar than the areas where fishermen set gear in the Pacific Ocean.

\section{Size Composition}

The overall mean size and length frequency distribution of escolar taken in the western North Atlantic Ocean (mean $=89.5 \mathrm{~cm} \mathrm{FL}$ ) was similar to that of the Pacific Ocean (90.0 $\mathrm{cm}$ FL) [29], but larger than those reported by Lorenzo and Pajuelo [31] in the eastern North Atlantic Ocean for round escolar. Because data in the eastern North Atlantic was collected from the hake hook-and-line fishery, it is probable that the difference in escolar length-frequency distribution re- 
sulted from either gear-size bias or was species size related. In the western South Atlantic Ocean, Milessi and Defeo [4] did not evaluate escolar length, but did evaluate weightfrequency distribution. Findings showed that weightfrequency distributions were uni-modal in all years, which was not evident in the present study for length-frequency. In general, the fishery in the western North Atlantic Ocean exploited a larger percentage of the length-frequency distribution range than the fishery did in the South Atlantic Ocean [4] or eastern North Atlantic Ocean [31], which might explain why catch rates have declined in the South Atlantic. The fork length to dressed weight association estimated for escolar in this present study was slightly lower than those calculated in the eastern North Atlantic (W $=4.7 \times 10^{-3}$ $\left.(\mathrm{L})^{2.96} ; \mathrm{r}^{2}=0.99 ; n=308\right)$, but weights for this study were obtained from fish that were gutted and a different escolar species. In contrast, weights obtained from the eastern Atlantic were whole weights and from round escolar species; therefore, a conversion rate between dressed weight and whole weight is necessary before these length-weight associations can be appropriately compared between the two species.

Escolar lengths varied by area, month, and year. The smallest escolar were taken in the South Atlantic Bight and the largest in South Atlantic Region suggesting that size increases from inshore to offshore waters. One explanation could be that escolar are distributed according to depth with smaller individuals found inshore (mean minimum depth $=$ $775 \mathrm{~m}$ ) and larger individuals found offshore (mean minimum depth $=1,500 \mathrm{~m}$ ).

Seasonal mean-length distributions were significantly different among months with the largest difference detected between March (mean = 100.1 cm FL, $n=124)$ and September (mean $=74.7 \mathrm{~cm} \mathrm{FL,} n=157)$. Interestingly, March was when the least number of escolar were taken and September was the month when catches of escolar were beginning to increase. Overall, the data showed that mean length increased from September to December. Again, this might be due to some type of seasonal reproductive behavior, but the lack of reproductive data (Gonadossomatic Index [GSI]) makes it is difficult to speculate this difference. In the eastern North Atlantic Ocean (Canary Islands), Lorenzo and Pajuelo [31] reported that the reproductive period for roudi escolar extends from April to September, and peaks in June and July. However, the smaller size-at-catch in September in this present study may not be associated with any biological behavior, but just a product of the data set. If the September catch data was excluded from these analyses, then the mean escolar length would be similar among months; thus, it is probable that this observation was associated more with the small sample size for September $(n=157$ or $5 \%)$ rather than for biological reasons.

Inter-annual mean length distributions were significantly different among years. The smallest (81.5 cm FL) escolar was taken in 1995 and the largest (95.7 cm FL) in 1993. Overall, escolar were smaller during the first time-series (1992-1995) than the second (1995-1999). Nonetheless, no correlations between mean size and time were evident, which disagrees with the finding for the western South Atlantic Ocean. In fact, Milessi and Defeo [4] found that the mode weight decreased from 24 (1982) to $15.8 \mathrm{~kg}$ (1996), and the mean weight was negatively correlated with time. Lengthfrequency analyses, along with the evaluation of catch rates in this present study do not support the notion of overexploitation. A recent updated analysis shows that escolar taken by the pelagic longline fishery in the western North Atlantic (1992-2005) are longer in length than the results presented in this study [33], which might be attributed to the new circle hook requirements for the U.S. pelagic longline fishery. Nonetheless, preliminary findings by Kerstetter and Armstrong [33] indicate that the mean escolar length in U.S. pelagic longline fishery is still relatively stable suggesting that the last 6 years of fishing pressure has had little effect on the escolar population. At this time, it is difficult to hypothesize how exploiting larger sizes of escolar in the western North Atlantic Ocean will impact the stock in the future, but this could be a future conservation and management issue. Assuming that age and growth for escolar in the western North Atlantic corresponds to that of the eastern North Atlantic round escolar [31], then exploited escolar catches in the western North Atlantic Ocean are already at maximum theoretical size-at-age (ages 9 and 10). Therefore, exploiting larger and older fish could significantly impact the stock if escolar catch rates and fishing effort was ever to increase in the western North Atlantic Ocean.

The sex ratio of male-to-female escolar was significantly different than the expected 1:1. Findings showed that the escolar sex ratio in the western North Atlantic favored females $(1: 1.86)$, which was similar to those reported $(1: 1.96)$ for catches of roudi escolar in the eastern North Atlantic [31]. The results in this present study showed that female escolar were significantly longer than male escolar, which contrasted with the findings by Lorenzo and Pajuelo [31, 34]. Actually, these investigators did not report any significant difference in length frequency distribution between male and female roudi escolar in the eastern North Atlantic. Although updated analysis by Kerstettter and Armstrong [33] do not report any sex ratio differences, the researchers did evaluate mean size by sex. Interestingly, their findings show that escolar mean size by sex has increased in recent times, which I speculate is probably associated with the new circle hook regulations rather than for biological reasons, but this unconfirmed. In summary, it is difficult to guess how and if this will impact the escolar stock, but with the fishery exploiting larger and more females than males, it possible that this may impair the future reproductive potential or success of escolar.

\section{CONCLUSION}

\section{Conservation and Management}

History has taught us that many of today's important economically-valuable and target species were once a bycatch species that had little to no value. Assuming this trend continues into the future, it is possible that as more restrictions are imposed on the pelagic longline fishery and populations of target catch continue to decline, that the importance of escolar and other secondary species will be elevated to conservation and management merit. Several authors assert that as target catches decrease, the fishery slowly shifts toward targeting secondary species, which thereby increases 
unit price and markets [35, 36]. Depending on the geographical region, often the local economics control fishing markets and industry, which could be problematic for conservation and management. Although this study did not show any evidence of escolar overexploitation in the western North Atlantic Ocean, data clearly indicate that escolar stocks in the western South Atlantic Ocean have declined [4], which could affect the entire population since only one population is found in the Atlantic Ocean [11].

Fishery market analysis is important to fishery managers because it allows for the monitoring of target and non-target catch. Recent analysis of escolar catches in the western North Atlantic Ocean (1992-1995) indicate that escolar landings have increased over time, which Kerstetter and Armstrong [33] suggest is evidence that the fishery is retaining a greater percentage of escolar. Is this a premature indicator that the pelagic longline fishery for escolar is shifting from a bycatch (non-target) to a target species? In fact, it appears that escolar prices and demand in Florida are increasing [33]. Often though, the shift from bycatch to target species occurs gradually over the course of many years, which emphasizes the importance of why fishery policy managers should encourage researchers to regularly assess catches of non-target species.

Fishery managers are challenged with increasing demand and declining fish stocks world-wide. In the U.S., NMFS indicates that some managed fish are classified as overfished and overfishing is occurring [37]. Although it is impossible for fishery managers to speculate on the economic future of bycatch, it would be wise to monitor commercial fishery markets and trends of secondary species. If fishery policy managers encourage these types of assessments, it could prevent secondary species from collapsing in the future. In fact, these types of studies on secondary species may even prevent overfishing from occurring as more information becomes available. It is often challenging for fishery policy managers to protect and conserve stocks after markets have already become established, especially for long-lived vulnerable species, such as sharks. Since fisheries continue to exploit and "fish down" trophic levels [28], the importance of conducting studies on less economically valuable or secondary species needs to be elevated in fisheries research, particularly if fishery management is moving toward ecosystem management.

To date, few studies have evaluated trophic dynamics in the open-ocean and there is no information available describing the role of escolar or other mesopelagic species in foodweb structure. Although no studies describe escolar trophic dynamics, one study hints that that escolar could play a role as a secondary prey-item for shortfin mako (Isurus oxyrinchus) and blue shark (Prionace glauca) [38]. This suggests that if escolar are negatively impacted by commercial fisheries then pelagic sharks could also be affected in the future. Ward and Myers [28] argue that we have no experience with understanding how shifts in the ecosystem will affect the overall stability and persistence of a system. As ecosystem management progresses, additional studies will need to evaluate the controlling processes within a given system with disregard to economics.

\section{ACKNOWLEDGMENTS}

I would like to thank the participants of the U.S. commercial pelagic longline fishery for the friendships, memories, and their awareness of safety during my 7 years as a fishery observer. I thank the National Marine Fisheries Service, Southeast Fisheries Science Center, for the financial support during 1995 through 2002. I would like to show my appreciation and admiration to D. Lee who served as the NMFS Pelagic Longline Observer Program (POP) coordinator (1992-2006) and C. Brown for providing escolar distribution data and map. I especially thank all the fishery observers that have collected data for the NMFS POP through out the duration of the program. In addition, I thank R. Spieler for initially reviewing this manuscript and D. Kerstetter for supporting and encouraging me to finally publish this dated study. Lastly, I thank D. Lee and G. Scott of NMFS for approving the use of this data set. Special thanks go to J. See and K. Dudzinski of GMI for reviewing and making editorial suggestions that greatly improved this manuscript.

\section{REFERENCES}

[1] Levesque JC. Establishment and closure of the directed Florida whiting (Menticirrhus americanus) fishery and implications for north Atlantic right whale (Eubalaena glacialis) Conservation and Management. Mar Policy 2009; 33: 233-47.

[2] NMFS (National Marine Fisheries Service). Implementing the sustainable fisheries act-achievements from 1996 to the present. USA: Silver Spring, MD 2003; p. 46.

[3] Alverson DL, Freeber MH, Murawski SA. A global assessment of fisheries bycatch and discards. J.G. Pope Series title: FAO Fisheries Technical Paper- T339 1994; p. 233.

[4] Milessi AC, Defeo O. Long-term impact of incidental catches by tuna longlines: the black escolar (Lepidocybium flavobrunneum) of the southwestern Atlantic Ocean. Fish Res 2002; 58: 203-13.

[5] Therkildsen NO, Petersen CW. A Review of the emerging fisheries for the sea cucumber Cucumaria frondosa: biology, policy, and future prospects. SPC Beche-de-mer Informat Bull 2006; 23: 16-25.

[6] Anderson SC, Lotze HK, Nancy L. Evaluating the knowledge base for expanding low-trophic-level fisheries in Atlantic Canada. Can J Fish Aquat Sci 2008; 65(12): 2553-71.

[7] Musick JA. Ecology and conservation of long-lived marine animals. In: Musick J.A, Ed. Life in the slow lane: ecology and conservation of long-lived marine animals. American Fisheries Society Symposium 23. Bethesda. Maryland 1999; pp. 1-10.

[8] Cochrane K, de Young C. Ecosystem approach to fisheries management in the Mediterrean. United Nations Food and Agriculture Organization. Opt Mediterranean 2008; 62: 71-85.

[9] Kinsolving AD, Bain MB. Fish assemblage recovery along a riverine disturbance gradient. Ecol Appl 1993; 3: 531-44.

[10] Boehlert GW. Biodiversity and marine fisheries. Oceanography 1996; 9(1): 28-35.

[11] Brendtro KS, McDowell JR, Graves JE. Population genetic structure of escolar (Lepidocybium flavobrunneum). Mar Biol 2008 155: 11-22.

[12] Nishikawa Y. Early development of the fishes of the family Gempylidae I. Larvae and juveniles of escolar, Lepidocybium flavobrunneum (Smith). Bull Far Seas Fish Res Lab 1982; 19: 1-19.

[13] Nakamura I, Parin NV. FAO species catalogue. Snake mackerels and cutlassfishes of the world (families Gempylidae and Trichiuridae). An annotated and illustrated catalogue of the snake mackerels, snoeks, escolars, gemfishes, sackfishes, domine, oilfish, cutlassfishes, scabbardfishes, hairtails, and frostfishes known to date. FAO Fisheries Synoposium 1993; vol. 125 no. (15), p. 136.

[14] Kerstetter DW, Rice PH, Snodgrass D, Prince ED. Behavior of an escolar, Lepidocybium flavobrunneum, in the windward passage as determined by popup satellite archival tagging. Gulf Caribb Res 2008; 20: 1-6.

[15] Lopes PR, Oliveira-Siva JT, Sampalo CLS, Olavo G. Reports of Gempylus serpens CUVIER, 1829, Lepidocybium flavobrunneum (Smith, 1849) and Ruvettus pretiosus Cocco, 1829 (Actinopterygil: Gempylidae) in inshore waters of Bahia State, Brazil. Arquivos de Ciências do Mar 2003; 36: 45-48.

[16] Quigley D, Flannery K. First record of escolar Lepidocybium flavobrunneum (Smith, 1849) (Pisces: Gempylidae) from Irish waters together with a review of NE Atlantic records. Irish Naturalist $2005 ; 28(3): 128-30$. 
[17] Kerstetter DW, Graves JE. Effects of circle versus J-style hooks on target and non-target species in a pelagic longline fishery. Fish Res 2006; 80: 239-50.

[18] Shadbolt C, Kirk M, Roche P. Editorial: Diarrhoea associated with consumption of escolar (rudderfish). Communicable Dis Intell 2002; 26(3): 436-38.

[19] Feldman KA, Werner SB, Cronan S. A large outbreak of scombroid fish poisoning associated with eating escolar fish (Lepidocybium flavobrunneum). Epidemiol Infect 2005; 133: 29-33.

[20] Lee DW, Brown CJ. SEFSC pelagic observer program data summary for 1992-1996. NOAA Technical Memorandum, NMFSSEFSC 1998; vol. 408: p. 25.

[21] Beerkircher LR, Brown CJ, Abercrombie DL, Lee DW. SEFSC pelagic longline observer program data summary for 1992-2002, NOAA Technical Memorandum NMFS-SEFSC 2004; vol. 522: p. 27.

[22] National Marine Fisheries Service (NMFS). Final rule. Atlantic highly migratory species (HMS); pelagic longline fishery. U.S. Fed Regist 2004; 69(128): 40734-58.

[23] Beerkircher LR, Cortes E, Shivji M. Characteristics of shark bycatch observed on pelagic longlines off the southeastern United States, 1992-2000. Mar Fish Rev 2002; 64(4): 40-9.

[24] Zar JH. Biostatistical Analysis. Prentice-Hall, Englewood Cliffs. Upper Saddle River, New Jersey. 1996.

[25] Bartlett MS. Some examples of statistical methods of research in agriculture and applied biology. J R Soc 1937; 4: 137-70.

[26] Bartlett MS. Properties of sufficiency and statistical tests. Proceedings of the Royal Society of London Series A 1937; 160: 268-82.

[27] Punsly R. Estimation of the relative annual abundance of yellowfin tuna, Thunnus albacares, in the eastern Pacific Ocean during 19701985. Inter-American Tropical Tuna Commission Bull 1987; 19: 263-306.
[28] Wards P, Myers R. Shifts in open-ocean fish communities coinciding with the commencement of commercial fishing. Ecology 2005; 86(4): 835-47.

[29] Nishikawa Y, Warashina I. Escolar, Lepidocybium flavobrunneum (Smith), commercially fished in the waters adjacent to the Pacific coast of Japan. Bull Far Seas Fish Res Laborat 1998; 25: 145-62.

[30] Levesque JC. NMFS SEFSC pelagic longline program 1999; Personal observation aboard U.S. commercial fishing vessels operating in the western North Atlantic Ocean.

[31] Lorenzo JM, Pajuelo JG. Population biology of the roudi escolar Promethichthys prometheus (Gempylidae) off the Canary Islands. Scientia Marina 1995; 59(3): 234-40.

[32] Nakano H, Okazaki M, Okamoto H. Analysis of catch depth by species for tuna longline fishery based on catch by branch lines. Bull Far Seas Fish Res Laborat 1997; 34: 43-62.

[33] Kerstetter DW, Armstrong BJ. Escolar catches in the U.S. Atlantic pelagic longline fishery. Unpublished; p. 39.

[34] Lorenzo JM, Pajuelo JG. Biology of a deep benthopelagic fish, roudi escolar, Promethichthys prometheus (Gempylidae) off the Canary Islands. Fish Bull 1997; 1: 92-9.

[35] Crowder LB, Murawski SA. Fisheries bycatch: implications for management. Fisheries 1996; 23: 8-17.

[36] Caddy JF. Fisheries management in the twenty-first century: with new paradigms apply? Rev Fish Biol Fish 1999; 9: 1-43.

[37] NMFS (National Marine Fisheries Service). 2008 status of U.S fisheries. USA: Silver Spring, MD 2008; p. 28.

[38] Amorim AF, Arfelli CA, Bacilieri S. Shark data from Santos longliners off southern Brazil (1971-2000). International Commission for the Conservation of Atlantic Tunas (ICCAT) 2002; vol. 54 no. (4): p. 1341-8.

(C) Juan C. Levesque; Licensee Bentham Open.

This is an open access article licensed under the terms of the Creative Commons Attribution Non-Commercial License (http: //creativecommons.org/licenses/by-nc/3.0/) which permits unrestricted, non-commercial use, distribution and reproduction in any medium, provided the work is properly cited. 